\title{
RELATIONS BETWEEN SOIL SURFACE ROUGHNESS, TORTUOSITY, TILLAGE TREATMENTS, RAINFALL INTENSITY AND SOIL AND WATER LOSSES FROM A RED YELLOW LATOSOL ${ }^{(1)}$
}

Julieta Bramorski $^{(2)}$, Isabella C. De $\operatorname{Maria}^{(3)}$, Renato Lemos e Silva ${ }^{(4)}$ \& Silvio Crestana ${ }^{(5)}$

\begin{abstract}
SUMMARY
The soil surface roughness increases water retention and infiltration, reduces the runoff volume and speed and influences soil losses by water erosion. Similarly to other parameters, soil roughness is affected by the tillage system and rainfall volume. Based on these assumptions, the main purpose of this study was to evaluate the effect of tillage treatments on soil surface roughness (RR) and tortuosity (T) and to investigate the relationship with soil and water losses in a series of simulated rainfall events. The field study was carried out at the experimental station of EMBRAPA Southeastern Cattle Research Center in São Carlos (Fazenda Canchim), in São Paulo State, Brazil. Experimental plots of $33 \mathrm{~m}^{2}$ were treated with two tillage practices in three replications, consisting of: untilled (no-tillage) soil (NTS) and conventionally tilled (plowing plus double disking) soil (CTS). Three successive simulated rain tests were applied in $24 \mathrm{~h}$ intervals. The three tests consisted of a first rain of $30 \mathrm{~mm} / \mathrm{h}$, a second of $30 \mathrm{~mm} / \mathrm{h}$ and a third rain of $70 \mathrm{~mm} / \mathrm{h}$. Immediately after tilling and each rain simulation test, the surface roughness was measured, using a laser profile meter. The tillage treatments induced significant changes in soil surface roughness and tortuosity, demonstrating the importance of the tillage system for the physical surface conditions, favoring water retention and infiltration in the soil. The increase in surface roughness by the tillage treatments was considerably greater than its
\end{abstract}

(1) Study of PhD Scholarship CNPq for publication in November 22, 2011 and approved in June 14, 2012.

(2) Biologist, doctor in Science in Environmental Engineering, University of São Paulo. Rua Padre Teixeira, 1772, CEP 13560-210 São Carlos (SP). E-mail: julieta@shs.com.br

(3) Agronomist engineer, doctor in Soil and Plant Nutrition, Researcher of Agriculture Institute of Campinas (IAC/SAA-SP). Av. Barão de Itapura, 1481 Caixa Postal 28, CEP 13012-970 Campinas (SP). E-mail: icdmaria@iac.gov.br

(4) Agronomist engineer, UFSCar. Master of Tropical and Subtropical Agriculture at Agriculture Institute of Campinas (IAC). Av. Barão de Itapura, 1481 Caixa Postal 28, CEP 13012-970 Campinas (SP). E-mail: renatolemos.silva@bol.com.br

(5) Physicist, doctor in Sciences. Researcher of EMBRAPA Instrumentation. Rua XV de Novembro, 1452, CEP 13560-970 São Carlos (SP). E- mail: crestana@cnpdia.embrapa.br 
reduction by rain action. The surface roughness and tortuosity had more influence on the soil volume lost by surface runoff than in the conventional treatment. Possibly, other variables influenced soil and water losses from the no-tillage treatments, e.g., soil type, declivity, slope length, among others not analyzed in this study.

Index terms: simulated rainfall, laser profile scanner, roughness index.

\title{
RESUMO: RELAÇÕES ENTRE A RUGOSIDADE SUPERFICIAL, A TORTUOSIDADE, O MODO DE PREPARO, A INTENSIDADE DE CHUVA E AS PERDAS DE SOLO E ÁGUA EM UM LATOSSOLO VERMELHO-AMARELO (LVA)
}

\begin{abstract}
A rugosidade superficial do solo aumenta a retenção e a infiltração de água no solo, reduz o volume e a velocidade do escoamento superficial e, dessa forma, influencia as perdas de solo por erosão hídrica. Entre outros, a rugosidade é alterada pelo método de preparo e pelo volume da chuva. Considerando essas premissas, realizou-se o presente trabalho com os objetivos de avaliar as modificações na rugosidade superficial (RR) e tortuosidade (T) do solo pelo método de preparo e investigar as relações com as perdas de solo e água ao longo de eventos de chuva simulada. $O$ estudo foi conduzido em campo, na área experimental da Embrapa Pecuária Sudeste (Fazenda Canchim), no município de São Carlos/SP, em parcelas experimentais de $33 \mathrm{~m}^{2}$, com dois tratamentos e três repetições. Os tratamentos utilizados foram: parcelas com solo sem preparo (NTS) e parcelas com preparo convencional (CTS) (aração+ duas gradagens). Foram realizadas três aplicações sucessivas de chuvas simuladas, com intervalos de 24 hentre elas, com as seguintes intensidades: primeira chuva com $30 \mathrm{~mm} / \mathrm{h}$, segunda chuva com $30 \mathrm{~mm} / \mathrm{h}$ e terceira chuva com $70 \mathrm{~mm} / \mathrm{h}$. Imediatamente depois do preparo e após cada evento de chuva, foram feitas leituras de rugosidade da superficie do solo por meio de um rugosímetro a laser. Os tratamentos resultaram em alterações significativas tanto no indice de rugosidade como no de tortuosidade, demonstrando a importância do preparo do solo sobre as condições físicas de superfície, favoráveis à retenção e infiltração de água no solo. O aumento na rugosidade induzida pelo preparo foi bem maior do que a sua diminuição pela ação da chuva. A rugosidade e a tortuosidade influenciaram mais os volumes de água escoados superficialmente do que a perda de solo em CTS. Possivelmente, em solo sem preparo existem outras variáveis, como tipo de solo, declividade do terreno, comprimento da rampa, entre outras não analisadas neste estudo, que, juntamente com os índices RR e T, influenciam as perdas de água e solo.
\end{abstract}

Termos de indexação: chuva simulada, rugosímetro a laser, índices de rugosidade

\section{INTRODUCTION}

Soil roughness describes the microvariations in surface elevation resulting mainly from management practices and is one of the main factors influencing wind and water erosion (Vidal Vázquez et al., 2005)

The onset of runoff roughness can be delayed by the surface roughness, by temporary water storage in the microdepressions of the soil, decreasing the runoff rate and volume and increasing sediment retention and, therefore, soil loss by erosion (Allmaras et al., 1966; Cogo et al., 1983; 1984; Onstad, 1984; Darboux \& Huang, 2005; Bertol et al., 2006).

The occurrence of runoff, and consequently, of material transport by erosion, depends on the rainfall volume and intensity, soil water infiltration, surface storage capacity (Cogo, 1981; Battany \& Grismer, 2000; Arnáez et al., 2007; Boulal et al., 2011), and terrain slope, among others. However, the water storage capacity of the soil surface depends almost exclusively on the surface roughness (Cogo, 1981; Kamphorst et al., 2000; Alvarez-Mozos, 2011).

In agricultural systems, the tillage methods can induce abrupt changes in the soil microrelief (Bertol et al., 2006; Castro et al., 2006; Bertol et al., 2007), increasing its roughness. However, rainfall gradually reduces this roughness (Paz González \& Castro, 1996; Eltz \& Norton, 1997; Kamphorst, et al., 2000; Bertol et al., 2007).

With the advances in research on soil erosion processes, the interest in measurement and modeling of the surface microrelief has increased, especially for 
use in mathematical models of soil loss using the evolution of surface water retention during rainfall events (De Roo et al., 1995; Govers et al., 2000).

The soil roughness is mainly characterized by two indexes: the roughness index $\mathrm{RR}$ (random roughness) (Allmaras et al., 1966; Currence \& Lovely, 1970) and tortuosity index $\mathrm{T}$ (Boiffin, 1984), both related to capacity of surface water storage in the soil (Onstad, 1984; Govers et al., 2000; Kamphorst et al., 2000).

Red Yellow Latosols cover great part of the state of Sao Paulo and the Brazilian Cerrado and are therefore a key focus of investigation from the point of view of management and conservation. However, for this as well as for other agriculturally important soils, little information is available on the relationship between surface water storage in soil and surface roughness.

The purpose of this study was to quantify the surface roughness of an Oxisol by determining the levels of random roughness (RR) and tortuosity $(\mathrm{T})$ and evaluate modifications induced by the tillage method and their relationships to soil and water loss during simulated rainfalls.

\section{MATERIAL AND METHODS}

The field study was conducted on an experimental area of EMBRAPA Southeastern Cattle Research Center in São Carlos (Fazenda Canchim), UTM coordinates 206219,7569671, in São Carlos/SP. The soil at the experimental site consists of an alic RedYellow Latosol, with moderate, sandy clay loam texture, on a $3 \%$ slope, which was used over years for experiments with no-tillage oat, basically. Some soil physical properties prior to the experiment are listed in table 1.

Table 1. Soil physical properties before the experiment

\begin{tabular}{|c|c|c|c|c|c|}
\hline \multirow[t]{2}{*}{ Treatment } & \multicolumn{2}{|c|}{ Particle } & \multirow{2}{*}{$\begin{array}{l}\text { size } \\
\text { Sand }\end{array}$} & \multicolumn{2}{|c|}{ Moisture Density } \\
\hline & Clay & Silt & & & \\
\hline \multicolumn{4}{|c|}{$\%$} & $\mathrm{~cm}^{3} / \mathrm{cm}^{3}$ & $\mathrm{~g} / \mathrm{cm}^{3}$ \\
\hline \multicolumn{6}{|c|}{ NTS* } \\
\hline 1 & 33.80 & 7.60 & 58.60 & 0.24 & 1.59 \\
\hline 2 & 33.20 & 7.30 & 59.50 & 0.25 & 1.50 \\
\hline 3 & 28.00 & 8.10 & 63.80 & 0.24 & 1.50 \\
\hline \multicolumn{6}{|c|}{ CTS* } \\
\hline 1 & 31.90 & 15.50 & 52.60 & 0.25 & 1.55 \\
\hline 2 & 30.80 & 9.60 & 59.60 & 0.23 & 1.55 \\
\hline 3 & 28.80 & 6.40 & 64.80 & 0.22 & 1.79 \\
\hline
\end{tabular}

*NTS: untilled soil, CTS: conventionally tilled soil.
Plots $(3.5 \times 11.00 \mathrm{~m})$ were established parallel to the slope of the experimental area. Each plot was delimited at the ends by plywood boards (width $0.20 \mathrm{~m})$, buried halfway $(0.10 \mathrm{~m})$ into the ground. A PVC pipe was fixed to a hole in the lower half of the board to lead the runoff to a collector box (volume of $1.0 \mathrm{~m}^{3}$ ). Two treatments with three replications were used: three conventionally tilled plots (CTS) (plowing plus double disking) and three untilled plots (NTS) (no-tillage).

Rain events were simulated using a rotating-boom rainfall simulator (Swanson, 1975), that watered two plots a time. Three successive rainfalls were applied, at 24-h intervals, at the intensities: 30,30 and 70 $\mathrm{mm} / \mathrm{h}$. Soil moisture was not monitored during the experiment, but the plots were covered up for 30 days before the experiment and after rain events, to avoid the influence of external factors.

The soil roughness was measured immediately after tilling, and immediately before the rains, in the plots without tillage, and after each simulated rainfall. All plots were maintained bare, without plants, straw or residues covering the surface.

The soil surface roughness was assessed using a laser profile scanner (Figure 1) coupled with a portable computer for automatic data recording (De Maria et al., 2003). This equipment covers an area of $1 \mathrm{~m}^{2}$ and determines the variation in elevation of data points spaced $1 \mathrm{~cm}$ apart, resulting in 10,000 evaluation points. The last 10 lines were excluded from the calculations, since the equipment does not allow reliable readings in this region, resulting in 9,000 data points.

The soil surface roughness index (RR) was calculated by the method of Allmaras et al. (1966), modified by Currence \& Lovely (1970), by multiplying the standard deviation of the elevation logarithms by the mean elevations. With the same data, the tortuosity index $(\mathrm{T})$ was calculated as proposed by Boiffin (1984), as the ratio between the soil profile

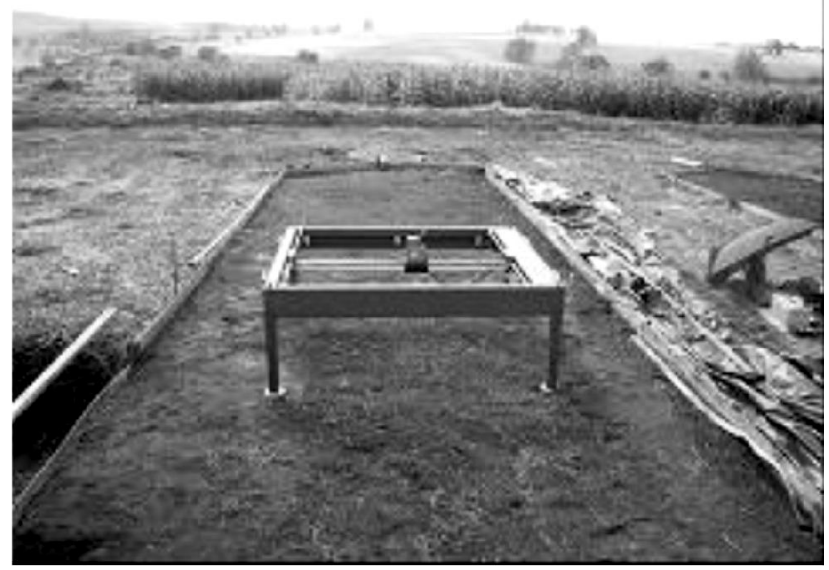

Figure 1. Laser profile scanner installed on one of the experimental plots. 
length, considering the microdepressions and microelevations, by the total soil profile length in a straight line.

To determine the volume of surface runoff and soil loss, the runoff was collected from each plot after each simulated rainfall. In the laboratory, the water volume and then the sediment concentration $(\mathrm{g} / \mathrm{L})$ were determined by evaporation.

The changes in surface roughness (RR) and tortuosity (T) of the soil after tilling, applied after the rains, as well as relations between the indices used and the soil and water losses were analyzed for each treatment.

\section{RESULTS AND DISCUSSION}

\section{Changes induced by tillage}

Before tillage, the roughness index (RR) ranged from 3.89 to 5.99 (Table 2), as similarly found by Panachuki et al. (2010), ranging from 3.31 to 5.41 for typic alumino-ferric Red Latosol.

The Student's ' $t$ ' test showed that before tillage, the $R R$ values in the plots did not differ significantly, and that an average of these values can be considered. The average RR before tillage was 4.79 , close to the random roughness value found by Bertol et al. (2006) in an Inceptisol under no-tillage (5.36).

After soil tillage, the $R R$ values ranged from 6.56 to 13.03 (Table 2). The Student's 't' test showed that the $R R$ after tillage did not differ significantly among plots either, so the averaged value of the replications (10.60) was used.

On average, the $R R$ values were 2.2 times higher after tillage, evidencing the influence of tillage on soil surface roughness. Moving the soil by tilling raises the soil surface level, inducing the creation of surface microdepressions and microelevations.

In a Cambisol, Bertol et al. (2007) found a 5.9-fold increase in the roughness of a bare soil before and after

Table 2. Indices of soil surface roughness (RR) and tortuosity $(T)$ in soil with conventional tillage and no tillage in three replications and their mean values, prior to the rainfall simulations

\begin{tabular}{ccccc}
\hline & \multicolumn{2}{c}{ RR } & \multicolumn{2}{c}{ T } \\
\hline Replication & NTS & CTS & NTS & CTS \\
1 & 3.89 & 12.21 & 44.82 & 73.76 \\
2 & 5.99 & 13.03 & 76.31 & 116.54 \\
3 & 4.48 & 6.56 & 51.08 & 78.58 \\
Mean & 4.79 & 10.60 & 57.40 & 89.62 \\
\hline
\end{tabular}

NTS : no-tillage soil; CTS: conventionally tilled soil. tillage. In a Hapludox on the other hand, Zoldan Jr. et al. (2008) found that conventional tillage increased the roughness by 1.9 times. Panachuki et al. (2010) found up to 3.8 times higher surface roughness after tillage in a typic alumino-ferric Red Latosol.

The tortuosity index $(\mathrm{T})$ before soil tillage varied between 44.82 and 76.31. Similarly as for RR, the mean of the replications (57.40) can be used, since no significant differences were detected by the Student's 't' test. In the CTS, the average T was 89.62 (Table 2).

The tortuosity index has the disadvantage of being strongly influenced by the scale factor (Kamphorst, 2000) and cannot be used to compare data measured at different spatial scales, since the greater the number of measured points, the higher the $\mathrm{T}$ value. Thus, the values obtained in this study are high, since all readings together resulted in 9,000 points. However, for the comparisons in this work this index is highly relevant, since it can explain the capacity of a surface to store water and delay the onset of runoff.

A comparison of means of the NTS and CTS showed that tillage increased tortuosity by $56 \%$. This is a significant increase, demonstrating the relevance of the tillage method in improving the soil surface conditions that influence the temporary water and sediment storage.

Figure 2 shows a three-dimensional representation of the soil surface before and after tillage, assessed with a laser profile meter.
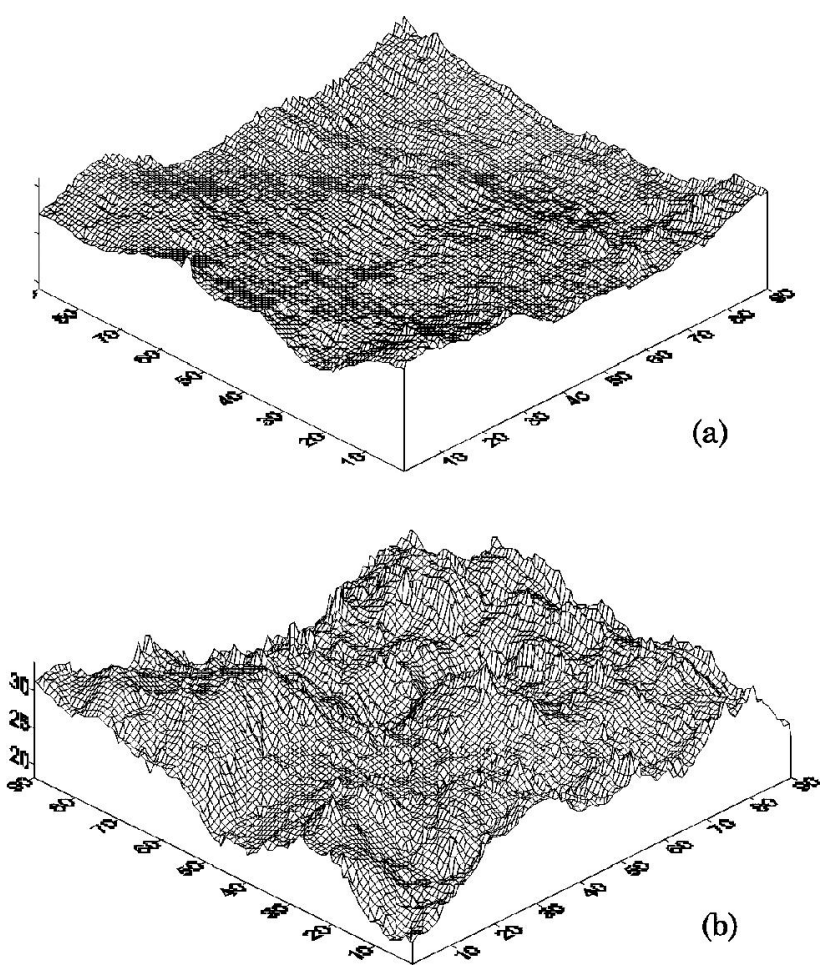

Figure 2. Three-dimensional representation of the soil profile before (a) and after tillage (b), assessed by a laser profile meter (in $\mathrm{cm}$ ). 


\section{Effect of rain on soil roughness and tortuosity}

The mean $R R$ values after rainfall application on untilled (NTS) and conventionally tilled soil (CTS) are shown in table 3 . The increase in surface roughness caused by tillage was much higher than its reduction by rain, as observed by Castro et al. (2006). Soil tillage increased the roughness by $121 \%$, while rain reduced it by only $6.50 \%$ in the untilled and by $3.80 \%$ in the conventionally tilled plots.

The rainfall intensity influenced the surface roughness values, with a tendency of decreasing more markedly in NTS, confirming observations of Bertol et al. (2006).

In the CTS plots, slight increases in RR were found after the first and after the last and most intense rain, compared to the rain in-between. This pattern is contrary to observations of Zoldan Jr. et al. (2008), Bertol et al. (2006) and Bertol et al. (2007), who reported a decrease in RR of bare CTS after rainfall simulations.

It can be inferred that in soil disturbed by tillage without cover, the first rain had the strongest impact on the surface in terms of degradation (Table 3). In the work of Eltz \& Norton (1997), Bertol et al. (2006, 2007), Zoldan Jr. et al. (2008). Panachuki et al. (2010), testing up to 5 times higher rain volumes, $R R$ was evidently decreased by successive rains, which could not observed in this study, due to the rainfall volume applied.

The tortuosity ( $\mathrm{T}$ ) of the soil decreased as a function of rainfall intensity, in agreement with results published by Vidal Vázquez (2002) and Bertol et al. (2006). The T values were reduced by the first rain in both treatments. The reduction was $23 \%$ in the soil without and $35 \%$ in the soil with conventional tillage. This decrease was less significant than after the last and most intense rainfall in both treatments. As observed and discussed above for the roughness index (RR), tortuosity (T) was also slightly increased after the first and after the last and most intense rainfall.

Tortuosity was influenced differently by rainfall than roughness. Despite the smaller variation in the

Table 3. Mean values of random roughness $(\mathrm{RR})$ and tortuosity (T) after each simulated rainfall event

\begin{tabular}{lrrrc}
\hline \multicolumn{5}{c}{ Rainfall intensity $(\mathbf{m m} / \mathbf{h})$} \\
\hline RR & $\mathbf{0}$ & $\mathbf{3 0}$ & $\mathbf{3 0}$ & $\mathbf{7 0}$ \\
NTS & 4.79 & 4.61 & 4.76 & 4.48 \\
CTS & 10.60 & 11.80 & 11.19 & 11.34 \\
& & $\mathbf{T}$ & & \\
NTS & 57.40 & 54.19 & 41.33 & 39.79 \\
CTS & 89.62 & 99.73 & 64.52 & 77.17 \\
\hline
\end{tabular}

NTS : no-tillage soil; CTS: conventionally tilled soil roughness values, the soil tortuosity evidently tended to be reduced at higher rainfall intensity. Roughness indicates the vertical variation and tortuosity the horizontal range of the microrelief, of which the latter is more influenced by rain action.

\section{Relations between soil roughness, tortuosity, runoff volume and soil loss by erosion.}

The values of RR, T, soil loss and water loss after the simulated rainfalls are listed in table 4 . The average of replications was used in both treatments for all values.

It was found that in no-tillage plots (Table 4), soil roughness decreased by $2.82 \%$ and soil loss by $21.14 \%$. The first rain, despite less intense, was capable of removing a higher amount of particles than each following rain. A possible explanation is that there was dispersed material on the soil surface which was carried away, for the most part, by the first rain. In the following rain events, less particles would have been removed because less material was dispersed, and the rain was not intense enough to break up more soil to carry away.

In CTS (Table 4), a reduction in sediment yield was observed as the initial roughness decreased. After the last rain, there was a marked increase of eroded soil, whereas the variation in roughness was minor. Comparing only the initial and final values as well, a decrease in surface roughness of $3.80 \%$ and an increase in soil loss of $166.29 \%$ was observed.

It is expected that less soil is lost from soils with higher surface roughness, as in the case of CTS, due to the trapping of particles in the microdepressions and slower runoff, than from smoother soils. However, the relationships found in this study showed that the soil loss from the NTS and consequently, less rough soil, was also lower than from CTS.

Table 4. Mean values of randon roughness (RR), tortuosity ( $T)$, soil loss, and water loss after the simulated rain events (intensity 30,30 and 70 $\mathbf{m m} / \mathbf{h}$ )

\begin{tabular}{|c|c|c|c|c|}
\hline Rain & $\mathbf{R R}$ & $\mathbf{T}$ & Soil loss & Water loss \\
\hline & & & $-\mathbf{g} / \mathbf{L}-$ & $-\mathbf{L}-$ \\
\hline \multicolumn{5}{|c|}{ NTS } \\
\hline 1 & 4.61 & 54.19 & 2.27 & 0.90 \\
\hline 2 & 4.76 & 41.33 & 1.10 & 1.07 \\
\hline 3 & 4.48 & 39.79 & 1.79 & 10.33 \\
\hline \multicolumn{5}{|c|}{ CTS } \\
\hline 1 & 11.80 & 99.73 & 2.67 & 0.40 \\
\hline 2 & 11.19 & 64.52 & 1.97 & 4.40 \\
\hline 3 & 11.34 & 77.17 & 4.44 & 5.59 \\
\hline
\end{tabular}

NTS : no-tillage soil; CTS: conventionally tilled soil. 
This pattern can be explained by the higher consolidation of the NTS used in this study. A possible explanation could be the lack of disturbance of the soil surface by tillage, making it more resistant to the disruptive action of raindrops. In this way, the low surface roughness may have been compensated by a higher trapping capacity of the soil particles, as also verified by Castro et al. (2006).

However, relating the values of soil loss and roughness of both NTS and CTS, a $\mathrm{R}^{2}$ of 0.4010 and $3 \times 10^{-5}$ was obtained, respectively, indicating that there is practically no relationship between the variables.

For tortuosity, the decrease in both treatments during the sequence of rain events was greater (26 and $22.62 \%$ in NTS and CTS, respectively) than the decrease in roughness.

When relating the values of soil loss and tortuosity, $\mathrm{R}^{2}$ was 0.0135 for CTS and to 0.5544 for NTS, indicating a low relationship between the variables, particularly in CTS.

Analyzing the volumes of surface runoff, it was found that the effects of the physical conditions caused by tillage, promoting water retention at the soil surface, were ephemeral, and diminished during the sequence of rain events (Table 4).

In CTS, the runoff water volume was lower after the last rain, when there was a small increase in roughness. In NTS, the runoff volume was highest after the last rainfall, when RR decreased.

This can be explained by the combined action of low roughness of the more consolidated NTS, resulting in low water retention and infiltration, and in a higher surface runoff volume. The same observation was reported by Castro et al. (2006).

The relationship between water loss through runoff and surface roughness resulted in values of $R^{2}$ of 0.8020 for CTS and 0.6889 for NTS, indicating that the soil roughness influenced the runoff rates more than the soil loss. This confirms again the importance of soil roughness induced by tilling, for water retention in the soil surface.

The ratio between the runoff volume and soil tortuosity resulted in $\mathrm{R}^{2}$ of 0.6972 and 0.3535 in CTS and NTS, respectively, showing that in CTS the tortuosity caused a reduction in water losses.

The water loss (runoff) from CTS during the rain events was lower than from NTS.

From the more consolidated NTS, the water losses during the less intense first and second rainfalls were significantly lower than water loss during the most intense rain (third rain), in which the soil infiltration capacity was exceeded by the water volume applied to the system.

Both the roughness (RR) as well as the tortuosity (T) indices affected water loss more than soil loss, on the surface of CTS.
It is worth remembering that the relationship between RR and T in CTS was significantly higher than in NTS, with $\mathrm{R}^{2}$ of 0.9853 and 0.0020 respectively. In the soil disturbed by tillage, the relationship between the elevations and depressions of the vertical (RR) and horizontal (T) soil profiles are more closely related, since the raindrop impact in this treatment has a greater capacity of surface degradation than on soil without tillage, where the more consolidated surface is also more resistant.

\section{CONCLUSIONS}

1. The method of soil preparation affected both the roughness $(\mathrm{RR})$ and tortuosity $(\mathrm{T})$ indices significantly, demonstrating the importance of soil tillage for the physical conditions on the soil surface.

2. The $R R$ and $T$ values decreased during the rain sequence in both tillage types; $T$ more than RR. However, the increase in surface roughness by soil tillage was greater than its decrease by rain. The first rain caused the greatest impact on the surface of the soil disturbed by tillage, evidenced by higher RR and $T$ values than before the rain events.

3. The decrease in $\mathrm{RR}$ and $\mathrm{T}$ indices induced an increase in sediment yield in soil with conventional tillage. In soil without tillage, sediment production decreased with the decrease in $\mathrm{RR}$ and $\mathrm{T}$.

4. In conventionally tilled soil (CTS), both RR and T influenced water loss more than soil loss. Possibly, there are other variables not analyzed in this study, which also have a strong influence on soil loss in CTS.

\section{ACKNOWLEDGEMENTS}

The authors are indebted to the National Council for Scientific and Technological Development - CNPq, for a $\mathrm{PhD}$ scholarship of the first author; to the State of São Paulo Research Foundation-FAPESP for research grants; to EMBRAPA Southeastern Cattle Research and Embrapa Agricultural Instrumentation for the physical support and infrastructure; and to the Agronomic Institute of Campinas - IAC for lending us the rainfall simulator and laser profile scanner.

The authors also wish to thank the reviewers of the Revista Brasileira de Ciência do Solo, for their suggestions and valuable observations, which contributed greatly to this work.

\section{LITERATURE CITED}

ALLMARAS, R.R.; BURWELL, R.E.; LARSON, W.E. \& HOLT, R.F. Total porosity and random roughness of the interrow zone as influenced by tillage. USDA Conserv. Res. Rep., 7:1-14, 1966. 
ALVAREZ-MOZOS, J.; MIGUEL ANGEL, C.; GIMENEZ, R.; CASALI, J. \& LEIBAR, U. Implications of scale, slope, tillage operation and direction in the estimation of surface depression storage. Soil Tillage Res., 111: 142-153, 2011.

ARNÁEZ, J.; LASANTA, T.; RUIZ-FLAÑO, P. \& ORTIGOSA, L. Factors affecting runoff and erosion under simulated rainfall in Mediterranean vineyards. Soil Tillage Res., 93:324-334, 2007.

BATTANY, M.C. \& GRISMER, M.E. Rainfall runoff and erosion in Napa valley vineyards: Effects of slope, cover and surface roughness. Hydrol. Process., 14:1289-1304, 2000.

BERTOL, I.; AMARAL, A.J.; VIDAL VÁZQUEZ, E.; PAZ GONZÁLEZ, A. \& BARBOSA, F.T. Relações da rugosidade superficial do solo com o volume de chuva e com a estabilidade de agregados em água. R. Bras. Ci. Solo, 30:543-553, 2006.

BERTOL, I.; PAZ GONZÁLEZ, A. \& VIDAL VÁZQUEZ, E. Rugosidade superficial do solo sob diferentes doses de resíduo de milho submetido à chuva simulada. Pesq. Agropec. Bras., 42:103-110, 2007.

BOIFFIN, J. Structural degradation of the soil surface by the action of rainfall. Paris, Inst. Natl. d'Agronomie ParisGrignon, 1984. (Tese de Doutorado)

BOULAL, H.; GÓMEZ-MACPHERSON, H.; GÓMEZ, J.A. \& MATEOS, L. Effect of soil management and traffic on soil erosion in irrigated annual crops. Soil Tillage Res., 11:62-70, 2011.

CASTRO, L.G.; COGO, N.P. \& VOLK, L.B.S. Alterações na rugosidade superficial do solo pelo preparo e pela chuva e sua relação com a erosão hídrica. R. Bras. Ci. Solo, 30:339$352,2006$.

COGO, N.P. Effect of residue cover, tillage induce roughness and slope length on erosion and related parameters. West Lafayette, Purdue University, 1981. 346p (Tese de Mestrado)

COGO, N.P.; MOLDENHAUER, W.C. \& FOSTER, G.R. Effect of residue cover, tillage-induced roughness, and runoff velocity on size distribution of eroded soil aggregates. Soil Sci. Soc. Am. J., 47:1005-1008, 1983.

COGO, N.P.; MOLDENHAUER, W.C. \& FOSTER, G.R. Soil loss reductions from conservation tillage practices. Soil Sci. Soc. Am. Proc., 48:368-373, 1984.

CURRENCE, H.D. \& LOVELY, W.G. The analysis of soil surface roughness. Trans. ASAE 13:710-714, 1970.

DARBOUX, F. \& HUANG, C. Does soil surface roughness increase or decrease water and particle transfers? Soil Sci. Soc. Am. J., 69:748-756, 2005.
DE MARIA, I.C.; STORINO, M. \& CASTRO, O.M. Equipamento com sensor a laser para medida da rugosidade da superfície do solo. In: CONGRESSO BRASILEIRO DE CIÊNCIA DO SOLO, 29., Ribeirão Preto, 2003. Anais... Botucatu, UNESP, 2003. v.1. p.1-4.

DE ROO, A.P.J.; WESSELING, C.G.; OFFERMANS, R.J.E. \& RITSEMA, C.J. LISEM: A user guide. Netherlands. Utrecht University, 1995. 49p.

ELTZ, F.L.F. \& NORTON, L.D. Surface roughness changes as affected by rainfall erosivity, tillage and canopy cover. Soil Sci. Soc. Am. J., 61:1746-1755, 1997.

GOVERS, G.; TAKKEN, I. \& HELMING, K. Soil roughness and overland ûow. Agronomie 20:131-146, 2000.

KAMPHORST, E.C.; JETTEN, V.; GUÉRIF, J.; PITKÄNEN, J.; IVERSEN, B.V.; DOUGLAS, J.T. \& PAZ, A. Predicting depressional storage from soil surface roughness. Soil Sci. Soc. Am. J., 64:1749-1758, 2000.

ONSTAD, C.A. Depressional storage on tilled soil surfaces. Trans. Am. Soc. Agric. Eng., 27:729-732, 1984.

PANACHUKI, E.; BERTOL, I.; SOBRINHO, T.A.; VITORINO, A.C.T.; SOUZA, C.M.A. \& URCHEI, M.A. Rugosidade da superfície do solo sob diferentes sistemas de manejo e influenciada por chuva artificial. R. Bras. Ci. Solo, 34:443$452,2010$.

SWANSON, N.P. Suggestions for use of the rotating-boom field plot rainfall simulator to obtain data for application of the soil loss equation. Entre-Rios, FAO, 1975. 65p.

PAZ GONZÁLEZ, A. \& TABOADA CASTRO, M.T. Medida del microrrelieve del suelo y estimación de la retención hídrica en depresiones de la superficie. In: GRANDAL D'ANGLADE, A. \& PAGÉS VALCARLOS, J.L., eds. REUNIÓN DE GEOMORFOLOGÍA, 4., A Coruña, 1996. p.829-841.

VIDAL VÁZQUEZ, E. Influencia de la precipitación y el laboreo en la rugosidad del suelo y la retención de agua en microdepresiones. A Coruña, Universidade de Coruña, 2002. 430p. (Tese de Doutorado)

VIDAL VÁZQUEZ, E.; VIVAS MIRANDA, J.G. \& PAZ GONZÁLES, A. Characterizing anisotropy and heterogeneity of soil surface microtopography using fractal models. Ecol. Model., 182:337-353, 2005.

ZOLDAN JR., W.A.; BERTOL, I.; PEGORARO, R.; FABIAN, E.L.; ZAVASCHI, E. \& VIDAL VÁZQUEZ, E. Rugosidade superficial do solo formada por escarificação e influenciada pela erosividade da chuva. R. Bras. Ci. Solo, 32:353-362, 2008. 
R. Bras. Ci. Solo, 36:1291-1297 